\title{
Combined Effects of Regular Aerobic Exercise with Vitamin D Supplementation on Some Apoptosis Indices in the Lung of Rats Exposed to Hydrogen Peroxide
}

\author{
Somayeh Ramezani (MSc) \\ Department of Exercise Physiology, \\ Islamic Azad University, Central \\ Tehran Branch \\ ORCID ID: 0000-0002-8247-5637 \\ Maghsoud Peeri (PhD) \\ Department of Exercise Physiology, \\ School of Physical Education and \\ Sport Sciences, Central Tehran Branch, \\ Islamic Azad University, Tehran, Iran \\ ORCID ID:0000-0003-1415-7319 \\ Mohammad Ali Azarbaijani (PhD) \\ Department of Exercise Physiology, \\ School of Physical Education and \\ Sport Sciences, Central Tehran Branch, \\ Islamic Azad University, Tehran, Iran \\ ORCID ID: 0000-0002-3502-7487 \\ Firoozeh Dehghan (PhD) \\ Department of Exercise Physiology, \\ School of Physical Education and \\ Sport Sciences, Central Tehran Branch, \\ Islamic Azad University, Tehran, Iran \\ ORCID ID: 0000-0002-6460-7528 \\ Corresponding author: Maghsoud \\ Peeri \\ Tel: +989111378737 \\ Email: fir_dhn@yahoo.com \\ Address: Department of Exercise \\ Physiology, School of Physical \\ Education and Sport Sciences, Central \\ Tehran
}

Received: 20 Oct 2018

Revised: 01 Dec 2018

Accepted: 04 Dec 2018

\section{cc) (i) (8)}

This work is licensed under a Creative

Commons Attribution 4.0 License.

\begin{abstract}
Background and Objectives: Exercise is a strong physiological stimulus that can affect apoptosis in the lungs by altering a number of extracellular and intracellular signaling pathways. The present study examined effects of regular aerobic exercise and vitamin I on expression of Bcl-2, Bax and caspase-3 in lung tissues of male rats exposed to hydrogen peroxide.
\end{abstract}

Methods: Forty-eight adult male Wistar rats were randomly assigned into six groups of eight, including 2 x H 20 2, $2 \mathrm{H} 20$ 2, Vit D (2HD), 2H202 + Regular Exercise Training (2HE), 2H202 + IJ3 + E (2HDE) ; Dimethyl sulfoxide (DMSO) and control (C). Subjects in the training groups performed aerobic exercise for eight weeks. Bax, Bcl-2, caspase-3 expression in the lung tissues was measured using RT-PCR.

Results: Bcl-2 expression in the exercise $(\mathrm{P}=0.004)$ and vitamin $\mathrm{D}(\mathrm{P}=0.006)$ groups increased significantly compared to the control groups. Bax, Bcl-2 and caspase-3 expression was significantly lower in the exercise group and vitamin I supplementation group compared to the control group. On the other hand, concurrent exercise and vitamin D significantly reduce Bax expression but had no significant effect on Bcl-2 and caspase-3 expression.

Conclusion: 0ur results demonstrate that regular aerobic exercise along with vitamin I supplementation may play a role in reducing apoptosis in lungs following severe oxidative stress.

Keywords: Apoptosis, Bcl-2, Bax, Caspase3, Aerobic Exercise, Vitamin ID.

This paper should be cited as: Ramezani S, Peeri M, Azarbaijani MA, F [Combined Effects of Regular Aerobic Exercise with Vitamin D Supplementation on Some Apoptosis Indices in the Lung of Rats Exposed to Hydrogen Peroxide]. mljgoums. 2019; 13(5):44-49 


\section{INTRODUCTION}

The lungs are constantly exposed to numerous harmful agents, such as cigarette smoke, mineral dust, ozone and harmful rays $(1,2)$. The majority of reactive oxygen and nitrogen species are thought to be produced by phagocytes or polymorphic cells as well as alveolar, branches or endothelial cells in the lungs. Evidence shows that oxidative stress plays a significant role in the pathogenesis of lung diseases $(3,4)$.

The damage caused by oxidative stress is involved in numerous diseases including neurological disorders, diabetes, atherosclerosis, arthritis, inflammation and most importantly, many types of cancer (5). Accumulation of reactive oxygen species (ROS) in cells results in activation of signaling pathways that regulate gene expression and alteration of protein synthesis/activity that eventually prepares the cell for adaptation to the new environment (6) or apoptosis (7). Certain proteins are involved in the molecular pathways of apoptosis (8). Members of the Bcl-2 family are the most important proteins involved in apoptosis regulation. These proteins are either anti-apoptotic (Bcl-2 and Bcl-XL) of proapoptotic (Bax, Bid). Activation of Bax and Bak results in increased permeability of the mitochondrial outer membrane and cytochrome c release from the intermembrane space into the cytosol $(9,10)$. This is followed by formation of apoptosome and activation of caspase- 9 that can directly activate caspases- 3 and $-7(11,12)$.

Vitamin D plays a significant role in maintaining homeostasis of different tissues including skeletal muscles, smooth muscles of vascular walls, myocardium and endothelium. It also has positive effects on cardiovascular function $(15,16)$. Recently, vitamin $\mathrm{D}$ has been identified as an antioxidant agent $(13,14)$ that might be associated with lung function. Low dietary intake of vitamin D and reduced sun exposure can influence the level of vitamin $\mathrm{D}$ and possibly the lung function (17). It is well-established that regular physical activity has beneficial effects on endurance, efficiency and functionality of the lungs and the respiratory system as a whole $(18,19)$. Almost all types of aerobic and anaerobic exercise can potentially increase oxidative stress in humans and animals, depending on the mode, intensity, duration and diet (20). It has been suggested that intensive eccentric exercise may be associated with increased apoptosis and DNA damage, whereas regular physical activity has anti-apoptotic effects (21).

In addition to identifying the molecular mechanisms involved in antioxidant functions, it is important to understand how such mechanisms influence oxidative stress in the lungs, which could ultimately help discovery of novel treatment strategies. Considering the contradictory findings surrounding the effectiveness of different physical activities on tissue apoptosis, this research was designed to determine the oxidative stress response to exercise and the role of vitamin D supplementation on apoptosis markers. For this purpose, we evaluated effects of an 8week aerobic exercise program with and without vitamin $\mathrm{D}$ supplementation on apoptosis indices of lung cells in rats exposed to hydrogen peroxide.

\section{MATERIALS AND METHODS}

In an experimental trial, 48 male Winstar rats (8-10 months old) weighting 20220 were purchased from the Shiraz University center for animals. The study was performed at the Kerman University of Medical Sciences, Iran. The animals were randomly placed in special polypropylene cages $(16 \times 30 \times 42 \mathrm{~cm})$. They were kept under standard conditions, controlled temperature $\left(22 \pm 2{ }^{\circ} \mathrm{C}\right)$ and a $12 / 12 \mathrm{~h} \mathrm{light/dark}$ cycle. The animals had free access to food and water. Later, the animals were randomly assigned into six groups of eight rats per cage: control, hydrogen peroxide $\left(\mathrm{H}_{2} \mathrm{O}_{2}\right)$, hydrogen peroxide plus vitamin $\mathrm{D}\left(\mathrm{H}_{2} \mathrm{O}_{2}+\mathrm{D} 3\right)$, hydrogen peroxide plus aerobic exercise $\left(\mathrm{H}_{2} \mathrm{O}_{2}+\mathrm{E}\right)$, hydrogen peroxide plus vitamin $\mathrm{D}$ and aerobic exercise $\left(\mathrm{H}_{2} \mathrm{O}_{2}+\mathrm{D} 3+\mathrm{E}\right)$ and dimethyl sulfoxide (DMSO). The study received approval from the ethics committee of the Kerman University of Medical Sciences. The experimental groups were exposed to toxic conditions via intraperitoneal injection of $1 \mathrm{mmol} / \mathrm{kg} \mathrm{H}_{2} \mathrm{O}_{2}$ three times a week $(22,23)$. The exercising rats performed the designed aerobic exercise program on a treadmill for 8 weeks 5 days per week. The rats in these groups were trained for two weeks on the treadmill at the speed of 10 to 15 meter per minute for 30 minutes to learn how to complete the exercise protocol. Then, they were assigned into6 group of 8 rats 
per group. The exercise groups performed the exercise with 55 to 60 percent of their Vo2max for 49 minutes on the treadmill slope set to 10 degree. the speed of running gradually increased up to the point of exhaustion For the warm up and cooling down purpose, the animals ran for 5 minutes at $40 \%$ of their Vo2max (24). In the first week of the exercise program, the animals ran at speed of $8 \mathrm{~m} / \mathrm{min}$ and on 8 degree slope for 30 minutes. In the second week, the speed was increased to 10 $\mathrm{m} / \mathrm{min}$. The increase of speed and duration continued until the $5^{\text {th }}$ week when the subjects were running at $20 \mathrm{~m} / \mathrm{min}$ for $60 \mathrm{~min}$ (24).

The rats in the HD and HDE groups received $0.5 \mu \mathrm{g}$ intraperitoneal injection of vitamin $\mathrm{D}$ daily for eight weeks (25). The vitamin D3 stock $(300000 \mathrm{UI} / \mathrm{ml})$ was purchased from the Caspian Co. (Tehran, Iran) under the generic name of Dithrecol. DMSO was used to make vitamin D3 soluble in normal saline, which was added to dilute the mixture to obtain the intended dose. A control groups received only DMSO to determine whether the solvent had any effect on the subjects.

All animals were sacrificed and the lungs were removed for examination. Twenty-four hours after the last exercise session, the lungs were removed to avoid additional internal production of ROS $(26,27)$. The samples were placed in liquid nitrogen and then stored at -75 ${ }^{\circ} \mathrm{C}$ for future examination.

After washing the samples with phosphate buffer saline, the samples were placed in RNA stabilization solution (RNAlater, Ambion, $\mathrm{L} / \mathrm{N}$ : 1206029). Total RNA was extracted from $30 \mathrm{mg}$ of tissue (ideal weight) using the
RNeasy Mini Kit (QIAGEN, Germany) according to the manufacturer's instruction. The extracted total RNA was kept at $-20{ }^{\circ} \mathrm{C}$ until future analysis. To carry out the twostage PCR, RNA samples were first transformed into cDNA. Reverse transcription to cDNA was done using qRT-PCR high capacity RNA to cDNA kit according to the manufacturer's instructions. The two-step real time qPCR technique was used to calculate gene expression during the PCR amplification process with application of TaqMan reagent. Briefly, $1 \mu \mathrm{l}(50 \mathrm{ng}) \mathrm{cDNA}, 5 \mu \mathrm{l}$ of main buffer, $1 \mu l$ herprot gene and $3.5 \mu l$ RNasefree water were loaded in wells. The experiments were conducted in triplicate and in a Step One Plus real time PCR machine (Applied Biosystems, USA). The Real time PCR program included reverse transcription at $48{ }^{\circ} \mathrm{C}$ for $15 \mathrm{~min}$, activation of ampli Taq gold DNA polymerase at $95{ }^{\circ} \mathrm{C}$ for $10 \mathrm{~min}$, denaturation at $95{ }^{\circ} \mathrm{C}$ for $15 \mathrm{sec}$ and annealing at $60{ }^{\circ} \mathrm{C}$ for $1 \mathrm{~min}$. The denaturation and annealing steps were performed for 40 cycles. Beta-actin and GAPDH were used as housekeeping genes. Fold changes of each target gene per average of beta-actin and GAPDH were calculated and considered as mRNA expression levels. Data were analyzed according to the comparative $\mathrm{Ct}\left(2^{-\Delta \Delta \mathrm{Ct}}\right)$ method (35). Table 1 shows sequences of the primers used in this study. GraphPad Prism was used to analyze the data using parametric tests including one-way analysis of variance (ANOVA), Tukey's post hoc test and two-way ANOVA. All statistical analyses were performed at significance level of 0.05 .

Table 1- Sequence of the primers used in the study

\begin{tabular}{|c|c|c|c|}
\hline Gene & Forward Primer & Reverse Primer & $\begin{array}{c}\text { Amplicon } \\
\text { length }\end{array}$ \\
\hline Bax & cccegtgagg gecgcacgtc tgcggggagt cacgtgaccg & $\begin{array}{l}\text { mdgsgdhlgg ggptsseqim ktgafllqgf } \\
\text { iqdraermag }\end{array}$ & 63bp \\
\hline Bcl-2 & cetcatgaaa taaaaagctg aaaggaattt gaataaaaat & $\begin{array}{c}\text { maqagrtgyd nreivmkyih yklsqrgyew } \\
\text { dtgdedsapl }\end{array}$ & 104bp \\
\hline Caspase-3 & gggatcaaag cttagtgtcc tgaggtgcgg agcttggaac & $\begin{array}{l}\text { mdnnetsvds ksinnfetkt ihgsksmdsg } \\
\text { iyldssykmd }\end{array}$ & 93 bp \\
\hline $\begin{array}{l}\text { Beta actin } \\
\text { (reference }\end{array}$ & $\begin{array}{l}\text { gtcgagtccg cgtccacceg cgagtacaac cttcttgcag } \\
\text { ctcetcegtc gecggtccac }\end{array}$ & $\begin{array}{l}\text { mdddiaalvv dngsgmckag fagddaprav } \\
\text { fpsivgrprh qgvmvgmgqk dsyvgdeaqs }\end{array}$ & 91 bp \\
\hline $\begin{array}{l}\text { Gapdh } \\
\text { (reference } \\
\text { gene) }\end{array}$ & $\begin{array}{l}\text { ggggetctet getcetcect gttctagaga cagccgcatc } \\
\text { ttcttgtgca gtgecagcet }\end{array}$ & $\begin{array}{l}\text { mvkvgvngfg rigrlvtraa fscdkvdiva indpfidlny } \\
\text { mvymfqydst hgkfngtvka }\end{array}$ & 174 bp \\
\hline
\end{tabular}




\section{RESULTS}

The results of one-way ANOVA indicated a significant difference in the mean level of Bax expression $(\mathrm{P}=0.0001)$. The Tukey's post hoc test results showed that Bax was significantly overexpressed in the solvent $(\mathrm{P}=0.001)$ and control $(\mathrm{P}=0.002)$ groups. The results of two-way ANOVA indicated that both exercise and vitamin $\mathrm{D}$ significantly decreased Bax expression. Bcl-2 expression in the $\mathrm{H}$ group was significantly less than in the solvent $(\mathrm{P}=0.046)$ and the control group $(\mathrm{P}=0.043)$. Administration of hydrogen peroxide $(1 \mathrm{mmol} / \mathrm{kg})$ and exercise program significantly increased $\mathrm{Bcl}-2$ expression. Bcl-2 overexpression was also observed in the vitamin D group, but combination of exercise and vitamin D supplementation had no significant effect on Bcl-2 expression.

Hydrogen peroxide caused a significant increase in the level of caspase-3 $(\mathrm{P}=0.0001)$. Caspase-3 level was significantly higher in the $\mathrm{H}$ group compared to the solvent $(\mathrm{P}=0.0001)$ and control $(\mathrm{P}=0.0001)$ groups. However, when $1 \mathrm{mmol} / \mathrm{kg}$ hydrogen peroxide was administered, exercise had no significant effect on caspase-3. Vitamin D had no significant effect on caspase-3 expression. Moreover, combination of vitamin D supplementation and exercise had no significant effect on caspase-3 expression (Figure 1).

Figure 1- Level of Bax, Bcl-2 and caspase-3 expression in the experimental groups

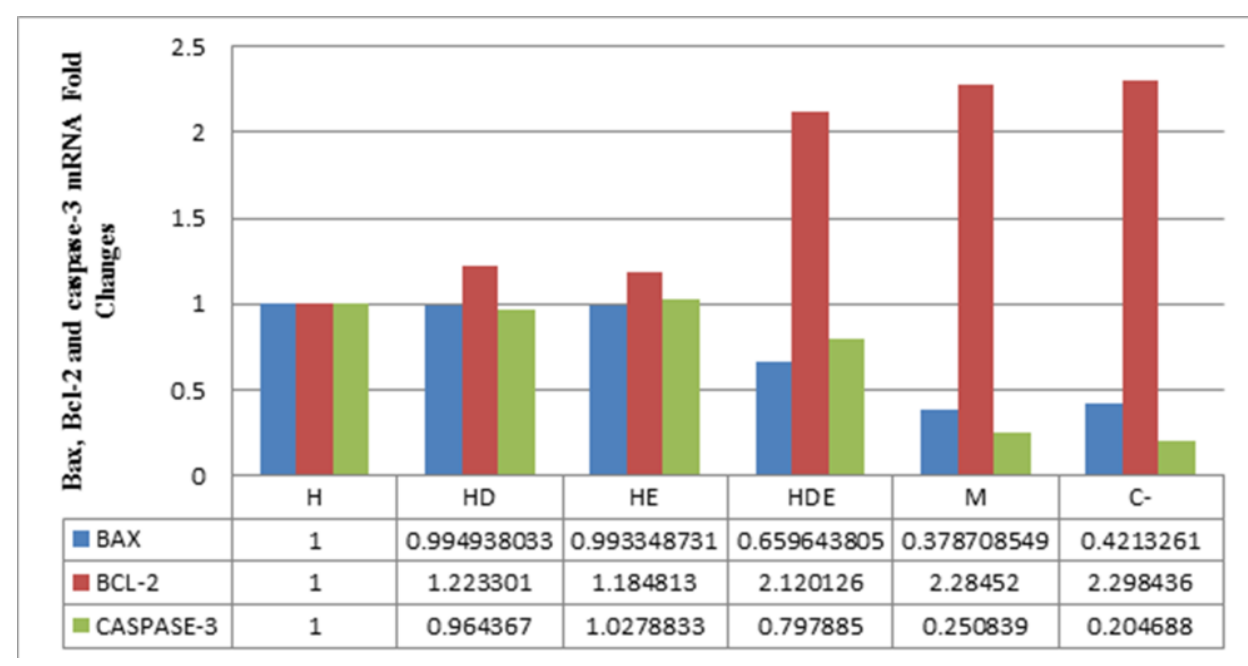

\section{DISCUSSION}

The present study examined the effects of exercise, vitamin D and artificially induced oxidative stress on Bax, Bcl-2 and caspase-3 expression in the lungs of rats. Regular exercise increases the resistance of respiratory muscles, which improves respiratory function and maximum exhalation output (28). In our study, hydrogen peroxide-induced oxidative stress resulted in an increase in Bax expression. It is well-demonstrated that oxidative stress can trigger apoptosis (29). Combination of exercise and vitamin D caused a significant decrease in Bax expression, which indicates the potential anti-apoptotic effect of the eight-week aerobic exercise program. As a proapototic protein, Bax is disruption and release of cytochrome $\mathrm{C}$ into cytozole. It also binds to $\mathrm{Bcl}-2$ and prevents its anti-apoptotic activity (30). Our findings are similar to results of a study by Fernandes that demonstrated increased Bcl-2 and decreased Bad expression can control apoptosis (31). Inconsistent with our findings, Phaneuf and Leeuwenburgh reported that Bcl-2 decreases and Bax increases immediately after exercise (32). This difference in the results could be attributed to the duration of the exercise programs (32).

Considering the fact that $\mathrm{Bcl}-2$ prevents the increase in Bax, it seems that the increase in Bcl-2 may be involved in the Bax suppression (33). It has been shown that Bcl-2 itself does not act as an antioxidant and may have indirect effects on intracellular antioxidant activities. In line with our findings, a study showed that intensive exercise impairs homeostasis and is associated with increased oxidative stress $(34,35)$. Fisher et al. also demonstrated that 
intensive interval training increases oxidative stress in cells (36). Free oxygen radicals can cause DNA damage and apoptosis in different organs, including the lungs (37). While such outcome is expected following intensive training, mild or moderate physical activities are thought to exert anti-apoptotic effects in different tissues $(38,39)$. In our study, aerobic exercise and vitamin D supplementation did not alter caspase-3 expression significantly. This may indicate the protective role of aerobic exercise against apoptosis in the lungs. Several mechanisms have been proposed for such protective role, including altered expression of anti- and pro-apoptotic proteins, increased mitochondrial biogenesis, improved mitochondrial function, decreased ROS level and increased antioxidant level (21). It has been suggested that supplementary antioxidants following internal antioxidant depletion are effective in improving performance; however, once the normal level of antioxidants is restored, it is unlikely to have any notable benefit (40).

\section{REFERENCES}

1. Fedirko V, Bostick RM, Flanders WD, Long Q, Shaukat A, Rutherford RE, et al. Effects of Vitamin D and Calcium Supplementation on Markers of Apoptosis in Normal Colon Mucosa: A Randomized, Double-Blind, Placebo-Controlled Clinical Trial. Cancer Prev Res (Phila). 2009; 2(3): 213-23.

2. Halliwell B, Gutteridge JMC. Free Radicals in Biology and Medicine. $3^{\text {rd }}$ ed. Oxford University Press, Oxford. 1999; 1-35.

3. Magi B, Bargagli E, Bini L, Rottoli P. Proteome analysis of bronchoalveolar lavage in lung diseases. Proteomics. 2006; 6(23): 6354-69.

4. de Torre C, Ying SX, Munson PJ, Meduri GU, Suffredini AF. Proteomic analysis of inflammatory biomarkers in bronchoalveolar lavage. Proteomics. 2006; 6(13): 3949-57.

5. Aldini G, Yeum J, Niki E, Russell RM. Biomarkers for Antioxidant Defense and Oxidative Damage: Principles and Practical Applications. Ames, IA: Wiley-Blackwell. 2010.

6. Heidarvand L, Maali-Amiri R. Physio-biochemical and proteome analysis of chickpea in early phases of cold stress. J Plant Physiol. 2013; 170(5): 459-69.

7. Franco R, Sanchez-Olea R, Reyes-Reyes EM, Panayiotidis MI. Environmental toxicity, oxidative stress and apoptosis: Menage a trois. Mutat Res. 2009; 674(12): 3-22.

8. Weinmann M, Jendrossek V, Handrick R, Güner D, Goecke B, Belka C. Molecular ordering of hypoxiainduced apoptosis: critical involvement of the mitochondrial death pathway in a FADD/caspase-8 independent manner. Oncogene. 2004; 23(21): 3757-69.

\section{CONCLUSION}

In summary, the results of this study showed that oxidative stress induced by hydrogen peroxide injection results in lung inflammation that may alter expression of Bcl2, Bax, caspase-3. Combination of aerobic exercise and vitamin $\mathrm{D}$ may play a protective role against apoptosis in the lungs.

However, further studies on other factors involved in apoptosis are required to confirm this finding.

\section{ACKNOWLEDGMENTS}

The first author would like to express her gratitude to Dr. Peeri, Ms. Dehghan and Prof. Azarbaijani for their valuable contribution and comments.

\section{CONFLICT OF INTEREST}

The authors declare that there is no conflict of interest regarding publication of this article.

9. Wei MC, Lindsten T, Mootha VK, Weiler S, Gross A, Ashiya M, et al. tBID, a membrane-targeted death ligand, oligomerizes BAK to release cytochrome c. Genes Dev. 2000; 14(16): 2060-2071.

10. Wei MC, Zong WX, Cheng EH, Lindsten T, Panoutsakopoulou V, Ross AJ, et al. Proapoptotic BAX and BAK: a requisite gateway to mitochondrial dysfunction and death. Science. 2001; 292(5517): 727730 .

11. Li P, Nijhawan D, Budihardjo I, Srinivasula SM, Ahmad M, Alnemri ES, et al. Cytochrome $c$ and dATPdependent formation of Apaf-1/caspase-9 complex initiates an apoptotic protease cascade. Cell. 1997; 91(4): 479-489.

12. Srinivasula SM, Ahmad M, Fernandes-Alnemri T, Alnemri ES. Autoactivation of procaspase-9 by Apaf-1mediated oligomerization. Mol Cell. 1998; 1(7): 949957.

13. Fuchs-Tarlovsky V. Role of antioxidants in cancer therapy. Nutrition. 2012; 29(1):15-21.

14. Barker T, Martins TB, Hill HR, Kjeldsberg CR, Dixon BM, Schneider ED, et al. Circulating proinflammatory cytokines are elevated and peak power output correlates with 25-hydroxyvitamin D in vitamin D insufficient adults. Eur J Appl Physiol. 2013; 113(6): 1523-34.

15. Holick MF. Vitamin D deficiency. The New England Journal of Medicine. 2007; 357: 266-281.

16. Polidoro L1, Properzi G, Marampon F, Gravina GL, Festuccia C, Di Cesare E, et al. Vitamin D Protects Human Endothelial Cells from H2O2 Oxidant Injury Through the Mek/Erk-Sirt1 Axis Activation. J Cardiovasc Transl Res. 2013; 6(2): 221-31. 
17. Tashkin DP, Celli B, Senn S, Burkhart D, Kesten S, Menjoge S, et al. A 4-year trial of tiotropium in chronic obstructive pulmonary disease. N Engl J Med. 2008; 359(15): 1543-54.

18. Kuepper T, Morrison A, Gieseler U, Schoeffl V. Sport climbing with pre-existing cardiopulmonary medical conditions. Int J Sports Med. 2009; 30(6): 395402.

19. Vieira R, de Andrade V, Duarte A, Dos Santos A, Mauad T, Martins M, et al. Aerobic conditioning and allergic pulmonary inflammation in mice. II. Effects on lung vascular and parenchymal inflammation and remodeling. Am J Physiol Lung Cell Mol Physiol. 2008; 295(4): L670-9.

20. Fisher-Wellman K, Bloomer RJ. Acute exercise and oxidative stress: a 30 year history. Dynamic Medicine. 2009; 8:1.

21. Quadrilatero J, Alway SE, Dupont-Versteegden EE. Skeletal muscle apoptotic response to physical activity: potential mechanisms for protection. Appl Physiol Nutr Metab. 2011; 36(5): 608-17.

22. Li SF, Liu HX, Zhang YB, Yan YC, Li YP. The protective effects of alpha-ketoacids against oxidative stress on rat spermatozoa in vitro. Asian J Androl. 2010; 12(2): 247-56. doi: 10.1038/aja.2009.78.

23. Makino A, Skelton MM, Zou AP, Cowley AW Jr. Increased renal medullary $\mathrm{H} 2 \mathrm{O} 2$ leads to hypertension. Hypertension. 2003; 42(1): 25-30.

24. Husain, Kazim, Stephen R Hazelrigg. Oxidative injury due to chronic nitric oxide synthase inhibition in rat: effect of regular exercise on the heart. Biochim Biophys Acta. 2002; 1587(1): 75-82.

25. Halder, Sunil K, Chakradhari Sharan, Ayman AlHendy. 1, 25-dihydroxyvitamin D3 treatment shrinks uterine leiomyoma tumors in the Eker rat model. Biol Reprod. 2012; 86(4): 116.

26. Novelli EL, Diniz YS, Galhardi CM, Ebaid GM, Rodrigues HG, Mani F,et al. Anthropometrical parameters and markers of obesity in rats. Lab anim. 2007; 41(1): 111-119.

27. Plant DR1, Gregorevic P, Warmington SA, Williams DA, Lynch GS. Endurance training adaptations modulate the redox-force relationship of rat isolated slow-twitch skeletal muscles. Clinical and experimental pharmacology and physiology. 2003; 30(1-2): 77-81.

28. Weiner P, Berar-Yanay N, Davidovich A, Magadle $\mathrm{R}$, Weiner M. Specific inspiratory muscle training in patients with mild asthma with high consumption of inhaled beta(2)- agonists. Chest. 2000; 117(3): 722-7.

29. Schieber M, Chandel NS. ROS function in redox signaling and oxidative stress. Curr Biol. 2014; 24(10): R453-62. 30. Wattenberg B, Lithgow T. Targeting of $C$ terminal (tail)-anchored proteins: understanding how cytoplasmic activities are anchored to intracellular membranes. Traffic. 2001; 2(1): 66-71.
30. Fernandes T, Magalhaes FC, Everton C. Aerobic exercise training inhibits skeletal muscular apoptotic signaling mediated by VEGF -VEGR2 in spontaneously hypertensive rats. Exercise and Sports Sciences 2012; 18(6): 412-418.

31. Phaneuf S, leeuwenburgh Ch. Apoptosis and exercise. Medicine and Science in Sports and Exercise. 2001; 33(3): 393-39633.

32. Bagci E, Vodovotz Y, Billiar T, Ermentrout G, Bahar I. Bistability in apoptosis: roles of bax bcl-2 ، and mitochondrial permeability transition pores. Biophysical Journal. 2006;90(5):1546-59.

33. Arslan S, Erdem S, Sivri A, Hasçelik Z, Tan E. Exercise-induced apoptosis of rat skeletal muscle and the effect of meloxicam. Rheumatology International. 2002; 21(4): 133-6.

34. Packer N, Pervaiz N, Hoffman-Goetz L. Does exercise protect from cognitive decline by altering brain cytokine and apoptotic protein levels? A systematic review of the literature. Exerc Immunol Rev. 2010; 16: 138-62.

35. Fisher G, Schwartz DD, Quindry J, Barberio MD, Foster EB, Jones KW, et al. Lymphocyte enzymatic antioxidant responses to oxidative stress following highintensity interval exercise. J Appl Physiol (1985). 2011; 110(3): 730-7.

36. Podhorska-Okolow M ‘Dziegiel P ،Gomulkiewicz A ، Kisiela D ‘Dolinska-Krajewska B ،Jethon Z ‘et al. Exercise-induced apoptosis in rat kidney is mediated by both angiotensin II ATI and AT2 receptors. Histol Histopathol. 2006; 21(5): 459-66.

37. Quadrilatero J, Bombardier E, Norris SM, Talanian $\mathrm{JL}$, Palmer MS, Logan $\mathrm{H}$, et al. Prolonged moderateintensity aerobic exercise does not alter apoptotic signaling and DNA fragmentation in human skeletal muscle. American Journal of Physiology-Endocrinology and Metabolism. 2010; 298(3): E534-E547.

38. McMillan EM, Graham DA, Rush JW, Quadrilatero J. Decreased DNA fragmentation and apoptotic signaling in soleus muscle of hypertensive rats following 6 weeks of treadmill training. Journal of Applied Physiology. 2012; 113(7): 1048-1057.

39. Buzina R, Suboticanec K. Vitamin C status and physical working capacity in adolescents. Int $\mathrm{J}$ Vitam Nutr Res. 1985; 7: 157-66. 